\title{
Mining or Our Heritage? Indigenous Local People's Views on Industrial Waste of Mines in Ghana
}

\author{
Samuel Awuah-Nyamekye ${ }^{1,2}$ and Paul Sarfo-Mensah 3,4 \\ ${ }_{1}^{1}$ Department of Religion $\mathcal{E}$ Human Values, University of Cape Coast, \\ ${ }^{2}$ Department of Theology \& Religious Studies, University of Leeds, \\ ${ }^{3}$ Bureau of Integrated Rural Development, Kwame Nkrumah \\ University of Science \& Technology (KNUST), \\ ${ }^{4}$ University of Venda (UNIVEN), \\ ${ }^{1,3}$ Ghana \\ ${ }^{2} U K$ \\ ${ }^{4}$ South Africa
}

\section{Introduction}

The mining industry, particularly gold may be said to be as old as human civilisation. The history of the extraction of minerals in the various indigenous societies across the world will attest to this. In Ghana, the history of small scale gold mining dates as far back as the 4th century when indigenous craftsmen made use of gold in diverse ways (Hayford et al., 2008). The search for gold took a higher dimension in 1471, when the Europeans arrived and the silent trade began. Commercial scale gold mining, however, is believed to have commenced in Ghana during the 19th century by the British (Tsikata, 1997; cited by Hayford et al., 2008:1).

The industry in the country has expanded over the years, and mining currently includes the extraction of gold, bauxite, manganese and diamond in commercial quantities. Among these, gold mining is the most prominent and contributed to $93 \%$ of the exports made in 2004 (Minerals Commission, Ghana, 2004; cited by Hayford et al., 2008:1). The country is one of the major gold producing countries; ranking $8^{\text {th }}$ in the world and second in Africa. (Chamber of Mines of South Africa) The mining sector currently (2008) contributes about 7\% of Ghana's total corporate tax earnings. It forms $41 \%$ of total export, $12 \%$ of Government revenue collected by the Internal Revenue Service and 5\% of the total GDP (Hayford et al., 2008).

The expansion of the industry in the country as elsewhere is characterised by improvement in the knowledge or technology in the extraction of the mines (Akabzaa and Darimini, 2001). This means that the volume of mining waste moves with its corresponding increase in the extraction of the minerals. However, the improvement in the technique in the extraction of the mineral has not corresponded with its waste management, rather very little investment has happened in that direction in Ghana due to lack of coordination among the relevant sector institutions (Akabzaa and Darimani, 2001:37). For example, several researches in the 
country as elsewhere have underscored that large and small scale mining processes impact negatively on the environment and the socio- economic status of the communities in which they operate (Hilson and Yakovleva, 2007; Hayford, et al., 2008). And while emphasis is placed on the processing of the ore body and its waste product disposal method as major sources of environmental pollution, not much has been done to improve them (Hayford, et al., 2008). Therefore, the typical waste product, tailings that consist of crushed ore and rock bodies after most of the needed metals have been removed, are retained in sedimentation ponds and piled up for future treatment, while the slime goes with the overflow into nearby streams. This practice normally leads to siltation of nearby streams, destroying aquatic fauna and flora (Hayford et al., 2008:2). Other effluent that also ends up in nearby streams and rivers introduce dissolved toxic elements into them. The result is the increase in health problems, like severe intestinal upsets, keratosis and skin cancer, sleep disorders and salivation problems (Steinnes and Berg, 1998; Amankwah and Anim-Sackey, 2003).

The multinational mining corporations that operate in Ghana, as commonly found in other developing world tend to place much interest in their profit margins than the environmental hazards that their activities cause. For instance, in 2001, Goldfields Limited spilled cyanide into River Asuman, which serves as the drinking water for communities such as Abekoase, Samahu, Tebe, and Huniso. This also resulted in the death of hundreds of fish, crabs and birds (Anane, 2001). The statutory institutions including Environmental Protection Agency (EPA) that have the responsibility to oversee the operations of these companies are challenged in terms of human and material resources and are therefore unable to adequately deliver on their mandates (see for example, Akabzaa and Darimani 2001: 37). Thus, the management of industrial waste from the ever expanding mining sector in the country poses a real challenge to the country.

In this chapter we seek to examine industrial waste in Ghana with special reference to mining. Our focus is on local people's views on the impact of the industrial waste from mining on the local socio-economic environment. Evidence will be drawn from three regions in Ghana where mining related problems are more pronounced-Western, Ashanti and Brong Ahafo regions. For instance, greater percentage of Ghana's gold is mined in western and Ashanti Region. The chapter has been organised into five sections. The first section comprises the introduction. Section two presents a brief historical background of mining in Ghana and a profile of the study communities. The study methodology is presented in section three. Section four contains the results and discussion. In this section we present among others the conceptualization of industrial waste, types of mining waste and their impact as well as mitigation interventions. Finally, the conclusions and recommendations are presented in section five.

\section{Brief historical background of the mining industry in Ghana}

The mineral industry in Ghana as has been noted pre-dates the arrival of Europeans in the country in 1471(Akabzaa and Darimani, 2001). The industry was vibrant at the preindependence period. For instance, Ghana was said to have accounted for $36 \%$ of total world gold output (8,153,426 fine ounces) between 1493 and 1600 (Tsikata, 1997).

No wonder that Ghana was known at that time as 'Gold Coast' until her independence in 1957. It has been estimated that over 14.4 million ounces of gold were produced between 
1471-1880 (Adadey, 1997). It has also been estimated that 2,488 metric tons (80 million ounces) of gold was produced in Ghana between 1493 and 1997 (Kesse, 1985; Ghana Chamber of Mines, 1998). It is on record that the first 'Gold Rush' was started by one Mr. Pierre Bonne, who was a French trader. He set up a company with several concessions in Ashanti region (Agra, 1997). However, mining as an organised industry, begun with gold production at the later part of the 19th century by the British and other foreign investors (Akabzaa and Darimani, 2001). Private Ghanaian gold miners were, however, banned from operating mines due to the promulgation of the Mercury Ordinance of 1932. This was the result of the Ghanaians preferring to work in their own mines rather than work for the Europeans (Akabzaa and Darimani, 2001).

The industry has now expanded tremendously. The country has 23 large-scale mining companies producing especially gold and other minerals such as diamonds, bauxite and manganese. Currently, Ghana has over 300 registered small scale mining groups and 90 mine support service companies. No wonder that Ghana is ranked Africa's second largest gold producer after South Africa and the 10th in the world (Hayford et al., 2008).

\section{Profiles of the study areas}

Ghana comprises ten administrative regions which are all noted to be endowed with rich deposits of gold and other minerals. However, the Western, Ashanti and Brong Ahafo regions are rated among the most prominent in term of mining activities. Indeed, the Western and the Ashanti regions have the largest investments in mining; Brong Ahafo has gained prominence recently because of the activities of the Newmont Gold Ghana Limited (NGGL). This has also been attributed to the ubiquitous artisanal miners, known in Ghana as "Galamsey" many of whom have relocated from the Western and Ashanti regions to this emerging gold enclave, particularly within the Ahafo Kenyasi area where NGGL operates. In this section we give a profile of the study area; Western, Ashanti and Brong Ahafo regions. We will also provide an overview of the three main mining communities; Tarkwa, Obuasi and Ahafo Kenyasi, where we interacted with local people on industrial waste (see section on Methodology).

According to Ghana fact sheet (Modern Ghana Media, MGM, 2010), the Western region covers an area of 23,921 square kilometres which is about 10 per cent of Ghana's total land surface. It is located in the south-western part of Ghana, bordered by Ivory Coast on the west, Central Region on the east, Ashanti and Brong-Ahafo Regions on the north and on the south by $192 \mathrm{~km}$ of coastline of the Atlantic Ocean. The population of the region is 1,924,577, constituting about 10 per cent of the total population of the country. The region is endowed with considerable natural resources, which give it a significant economic importance within the context of national development. It is the largest producer of cocoa, rubber and coconut, and one of the major producers of oil palm. The rich tropical forest makes it one of the largest producers of raw and sawn timber as well as processed wood products. A wide variety of minerals, including gold, bauxite, iron, diamonds and manganese are either being exploited or are potentially exploitable. The region's total geological profile and mineral potential are yet to be fully determined. The Western Region is the largest producer of cocoa and timber, the second highest producer of gold, with the potential to become the highest producer of this commodity. There are five major gold mines, namely Teberebie and Iduaprem goldfields, both now owned by Ashanti goldfields, Prestea/Bogoso mines now 
owned by a South African company, Tarkwa goldfields, and Aboso goldfields located at Damang near Huni Valley. There are other proven but as yet unexploited ore deposits at Tarkwa, Aboso, Bondaye, and the forest reserve areas of Jomoro and Nzema East, AowinSuaman, Amenfi and Mpohor-Wassa-East districts.

Tarkwa, our study community in the Western region as indicated above, is a major gold mining centre not only in the region but Ghana as a whole. For example, Hayford et al. (2008) noted that although Anglo Gold Ashanti and Newmont, two of the major producers of gold in Ghana are in the Ashanti Region, the largest concentration of mining companies are, however, found in the Tarkwa-Wassaw District. Tarkwa our study community is the district capital. The 2010 Ghana Population Census estimated the community's population as 33, 466 (Ghana Statistical Service, 2010).

The community and its environs are characterised by an undulating terrain with a magnificent drainage system. It experiences the heaviest and most frequent rains in the country (Akbazaa and Darimani, 2001). The environmental challenges as result of industrial activities in the community and its environs are summarized by Akbazaa and Darimani (2001:30):

The heavy concentration of mining activities in the area has generated environmental and social issues in the area. The issues centre on resettlement and relocation, negotiation and compensation and environmental damage. The persistence of these socio-environmental problems accounts for the occasional and frequent resistance from the affected communities as well as clashes between them and the mining companies. The destruction of sources of livelihood and the spate of resistance and clashes have given rise to an environmentally conscious population from which local social movements are emerging.

Obuasi, our second study community, is a major commercial and industrial centre in the Ashanti Region, the third largest of the 10 administrative regions in Ghana (MGM, 2010). The region occupies a total land surface of 24,389 square kilometres or 10.2 per cent of the total land area of Ghana. In terms of population, however, it is the most populated region with a population of 3,612,950 in 2000, accounting for 19.1 per cent of Ghana's total population (MGM, 2010). Kumasi the regional capital, is the second largest city in Ghana. Much of the region used to be forested but it has witnessed massive deforestation in the past few decades mainly as result of clearing of forest for agriculture which provides employment for more than half of its economically active population (MGM, 2010).

The Obuasi township is the administrative capital of the Obuasi Municipality Assembly (OMA). The community and its environs have been experiencing tremendous socioeconomic challenges, especially rapid population growth and environmental degradation due to several years of mining (Sarfo-Mensah et al., 2010). The estimated population of the Municipality is 205,000 with an annual growth rate of $4 \%$, making it one of the fastest growing districts in the country (Ghana Statistical Service, 2010). The inception of the Economic Recovery Programme (ERP) in 1984 and the subsequent expansion of mining activities, particularly production at AngloGold Ashanti (AGA), led to the establishment of several subsidiary companies, service and commercial activities which are either directly or indirectly related to mining. The resultant inflow of migrants into Obuasi township and its catchment areas in search of jobs has over the years had negative social, economic, cultural and environmental impacts such as illegal mining, high prevalence of prostitution and 
HIV/AIDS, and high crime rates. Some attempts have been made by the OMA, NGOs, religious bodies, government agencies and AngloGold Ashanti to solve the unemployment problems in the municipality (Sarfo-Mensah et al., 2010: 2). These attempts, however, have achieved little success. There has, therefore, been a steady increase in unemployment, particularly among the youth since 1984 which has been noted to mainly account for the high prevalence of illegal mining activities and exacerbation of the environmental conditions in the area (Sarfo-Mensah et al., 2010:2).

The Brong Ahafo Region, the third study region covers an area of 39,557 square kilometres and shares boundaries with the Northern Region to the north, the Ashanti and Western Regions to the south, the Volta Region to the east, the Eastern Region to the southeast and La Cote d'Ivoire to the west. The region lies in the forest zone and is a major cocoa and timber producing area (MGM, 2010). The northern part of the region lies in the savannah zone and is a major grain and tuber producing region. The total population of the region is $1,815,408$, representing 9.6 per cent of the country's population. The region is more populous than only four other regions though it is the second largest in terms of land area. The main occupation of the workforce of the region is in agriculture which employs about $68.6 \%$ of the economically active population (MGM, 2010).

The Newmont Gold Ghana Limited (NGGL) Ahafo gold property is based in the towns of Kenyasi and Ntotoroso in the Brong-Ahafo region. Production of gold in the two communities which started in 2006 was expected to be about 17,100 kilograms per year (kg/yr) (reported as 550,000 troy ounces) with a mine life estimated at more than 20 years (Bureau of Integrated Rural Development, BIRD, 2009a). The Kenyasi Township, our third study community has had its population increasing rapidly since inception of the operations of NGGL started in the communities in 2006. This has led to soaring prices of food and rent charges leading to high cost of living. The population increase has also brought about congestion in the use of some social facilities including water and sanitation (BIRD, 2009a). A massive inflow of illegal miners into the community and its environs is reportedly leading to the destruction of the farm lands and loss of employment of the youth whose livelihoods depend on farming. A major challenge in the community and its catchment area is environmental management due to mining and its related activities (BIRD, 2009a).

\section{Methodology}

The study methodology was participatory and mainly community-based. We scaled it up at the district and the regional levels to interact with local non-governmental organisations (NGOs), technocrats and government officials to triangulate views collected at the community level, and to collect secondary data. Thus, both primary and secondary data were collected for the study.

The primary data was mainly based on interaction with people in the following communities: Ahafo Kenyasi in the Brong-Ahafo region; Tarkwa in the Western region; and Obuasi in the Ashanti region (see Figure 1). These communities and their catchment areas are all prominent gold mining enclaves in Ghana. In the communities, participatory approaches were used to interact with the following groups: chiefs and opinion leaders; elderly males; elderly females; the youth (men and women groups); and children (between the ages of six and 18 years). Our groups were selected to ensure that gender views were 


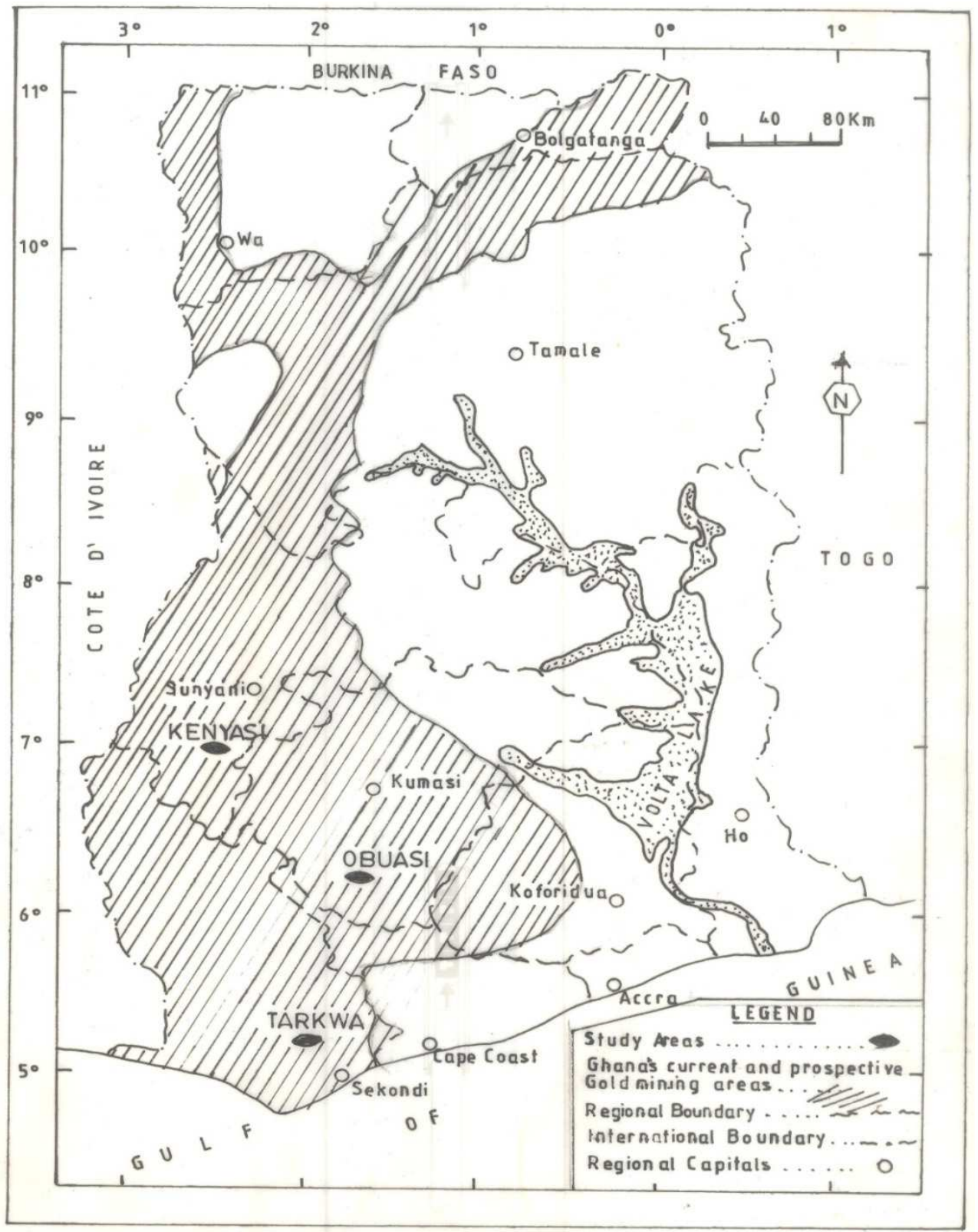

MAP OF GHANA SHOWING THE STUDY AREAS

Source: the authors' construct 2011

Fig. 1. Map of Ghana showing Study Areas 
captured. And, most importantly, children whose views are critical in society but often ignored in community engagement, was captured as well. And as indicated above, the participatory methodology was achieved by holding focus groups discussions with all our five carefully selected groups through the use of structured and semi-structured interviews. The focus of the discussions centred on the effects of mining especially mining waste on the lives of the people and the environment as a whole. Another key area of concentration was on the local people's environmental conservation strategies particularly on waste management. The possibility of integrating local knowledge with that of the modern means of waste management was also touched on.

The desk studies comprised mainly a review of relevant government documents and reports as well as reports produced by NGOs that operated in the study area. We also reviewed literature on industrial waste in the global, African and national context.

\section{Industrial waste conceptualised}

Industrial waste refers to waste resulting from industrial activity such as activities from factories, mills and mining and others. Some of these wastes may exist in liquid or solid form, some of which are hazardous -- those from automobile repair shops, petroleum and petrochemical industry, mining industry, etc. (see Books et al. 1976; Munson-McGee et al., 1996; Chaudhary and Rachana, 2006; Moreno et al. 2009). That is, they are or pose potential threats to both human and the environmental health. Those harmful wastes are characterised by ignitability (waste oil), corrosivity (e.g. battery acid), reactivity, toxicity, infectious or pathogenic. There are, however, many industrial wastes that are neither dangerous nor harmful. For instance fibre resulting from agriculture and logging is neither hazardous nor toxic.

Since the 'Industrial Revolution' 1 , industrial and mining operations have been accompanied by the problem of industrial waste, thus, making industrial waste a by-product of the Industrial Revolution. This waste is generated from the production process through the use and the disposal of manufactured products. Currently in Ghana, apart from the wastes generated from mining activities, the following are the main activities from which wastes are generated: "the textiles industries (Spinning, weaving, finishing, bleaching and dyeing, printing); food and beverages (fish processing, slaughter houses, breweries, soft drinks, fruit processing, oil processing, cocoa processing and flour mills); Petroleum and petrochemical industry; Wood processing industry (Sawmills, veneer processing, ply mills, furniture); Plastics and foam industry; paper, printing and publishing industry; Pharmaceutical industry; and the Paints and chemical industry" (see 18th Session of the United Nations Commission on Sustainable Development, National Report for Ghana Waste Management in Ghana). The basic concern of the Industrial Revolution has been the appropriate ways of managing industrial waste in order to avoid or mitigate their adverse environmental or human health impacts.

Managing industrial wastes has been a big source of worry to Ghana. The bane of the problem has been the lack of the requisite technical know-how, capital resources and the

'We refer to 'Industrial Revolution' as the major industrialisation that took place during the late 16th (1700s) and the early $17^{\text {th }}$ centuries (1800s), which begun in the Great Britain was rapidly replicated throughout the world. 
lack of political will by the various governments of Ghana (mostly paying lip-services to the issue since the policy, legal and institutional frameworks put in place are not strictly implemented). Although many of the industries have tried to do something by way of trying to recycle their waste products, their efforts have not been enough to contain the increasing volume of the current industrial waste level in the country. This chapter as has been pointed out examines the industrial waste in Ghana with special reference to mining waste.

\section{Mining and the economy of Ghana}

The contribution of the mineral industry to Ghana's economy is enormous. For instance, as back as 1991, the mining industry overtook cocoa as the largest foreign exchange earner for Ghana (Adadey, 1997). Minerals alone account for $40 \%$ of the Ghana's total gross foreign exchange earnings. Over 20,000 people are employed by the large scale mines whiles the small scale artisanal mining, especially gold and diamond, employ more than twice the number engaged by the large scale mining (Adadey, 1997). These figures appear to be conservative estimates. For example, according to Hilson (2001) an estimated 30,000 small scale miners work on registered plots while, 170,000+ are illegal galamsey. The contribution of small scale mining has been succinctly captured by Amankwah and Anim-Sackey (2003:133) as following:

The small-scale mining of these precious minerals has made significant socioeconomic impact on many individuals and communities since it provides both part-and fulltime jobs for the people and in some cases it is the only source of income available to the people. In the rural communities where mining takes place, the activity has reduced rural exodus, promoted local economic development and contributed towards poverty reduction. In addition, the mining operations are useful in basic skill development and contribute to the transformation of unskilled labour into semi-skilled and skilled workers. More importantly, due to the low barriers to entry in terms of capital needs and formal educational requirements, small-scale mining operations offer excellent opportunities for the evolution of indigenous entrepreneurs. In rural areas where other jobs are low paying or non-existent, small-scale mining appears as a valuable source of employment. The sector also provides raw materials for local industries.

But as we discuss later, the small scale mining sector is a significant contributor to industrial waste in the mining industry in Ghana and generally regarded as the principal actor in land degradation due to their ubiquity and uncontrolled nature (Anane, 2001; Akabzaa and Darimani, 2001:26).

Gender related activities have also been highlighted in the mining sector, especially regarding females participation in the industry (Hilson 2001; Hinton et al., 2003). There are several activities, especially in artisanal mining, where women are said to be predominating, for example, in sieving, sorting, the transport of ore and water, in cooked food selling, petty trading and providing other essential support services (e.g. washing of the ore) to the male miners. According to Hilson (2001) quoted by Hinton et al., (2003:3-5) women in artisanal mining constitute the following: acting as licensed buyers $(6 \%)$; concession holders $(10 \%)$; and work group sponsors or participants (15-20\%); women comprise approximately $15 \%$ of the legal small- scale metal mining labour force in Ghana; and their involvement in the illegal galamsey industry is up to 50\%. And as noted by Hinton et al. (2003: 1) for many women, artisanal mining signifies an opportunity to relieve the strains of poverty. 
In rural communities, where mining activities have seen an upsurge, the contribution of the industry to the local economies in terms of investment in people and infrastructure has been acknowledged by government and local people. These have ranged from housing and resettlement programmes, alternative livelihoods and direct training to employment opportunities for local people. Most mining companies are facilitating the management of comprehensive social responsibility programmes which fund these development projects. An example we found in our study area is the Newmont Ahafo Development Foundation of NGGL. As part of the company's social responsibility commitments, and through series of consultations and discussions with the relevant stakeholders including Traditional Authorities, District Assemblies, Regional Coordinating Council, Youth Groups, Women Groups, Farmers Groups and local NGOs, Newmont signed Social Responsibility Agreement with the communities around the Ahafo Mine in May 2008 (BIRD, 2009b). This agreement resulted in the setting up of Newmont Ahafo Development Foundation (NADeF) which is being supported by NGGL with $\$ 1$ per oz of gold produced and $1 \%$ net profit. The fund is estimated to generate about $\$ 600,000$ annually which will be used to support sustainable development projects and programmes in ten (10) communities namely; Kenyasi No.1, Kenyasi No.2, Ntotoroso, Gyedu, Wamahinso (all in Asutifi District), Yamfo, Susuanso, Terchire, Afrisipakrom and Adrobaa (all in Tano North District). The initial amount deposited by Newmont into the Fund is about \$850,000 (BIRD, 2009b:36).

The Foundation is now a registered entity under the laws of Ghana with a Nine-Member Board of Trustees to manage the fund. The Foundation has set up a Secretariat to manage the day-to-day administration of the fund and a Tender Board to handle the tendering processes for projects under the Foundation. To ensure that the purpose for which the fund has been established is realized in a timely, cost effective, transparent and sustainable manner, the Agreement also requested the ten communities to establish Sustainable Development Committees in their respective communities to lead and manage the development processes (BIRD, 2009b: 36). Apart from the mainstream mining companies, it must also be noted that in rural communities, significant numbers of inhabitants are attracted to small-scale mining because the industry pays substantially higher wages than most other sectors of industry (Hilson, 2001: 8).

In major urban mining settlements such as Obuasi and Tarkwa, most social and economic activities revolve around the mines. In Obuasi, the entire local economy depends on AngloGold Ashanti. For instance, educational infrastructure, markets, roads and lorry stations have been built by the Municipality with funding support from the company (SarfoMensah, et al, 2010). Business in the township is driven by incomes from miners. Indeed, responses from our respondents indicated that from children up to adults, everybody has something to do with the mining conglomerate. Although most of respondents were quick to add that because of the mines, cost of living is very high and several social vices are on the increase (see section 7 below). Socio-economic dependency on mining activities in communities where mining giants such as AngloGold Ashanti operate in Ghana is so pervasive that a slowdown in their businesses leads to virtual collapse of the local economies.

Mining has arguably made tremendous contributions to the socio-economic development of the country and its potential, as presented by the country's trade figures, is very enormous. In 2000 Ghana was ranked 8th in the world for gold production (Chamber of Mines of South Africa 2005). According to The Ghana Minerals Commission (2002), Ghana produced 
2,241,125 ounces of gold and the revenue accruing from this was $\$ 646.00$ million in 2002 . Also, according to the Business Monitor (2011) gold production was up by $3.5 \%$ year on year (y-o-y), at $1.46 \mathrm{mn}$ oz by 2010 with gold export earnings standing at US $\$ 1.68 \mathrm{bn}$. These figures indicate that Ghana derives substantial revenue from the mining sector, it is, however, estimated that only $30 \%$ of overall mining revenue remains in the country (Akabzaa 2009).

\section{The negative impact of mining on Ghana}

Mining as an industry has given society tremendous benefits. In terms of wealth creation, it is ranked amongst the highest income earners for many countries. However, its negative impact on society has been very significant. In this section, we discuss local people's views on the consequences of mining with emphasis on its industrial waste.

In our study communities, the negative impact of mining was defined severally perhaps due to the complexity of the problems that local people associated with mining. These were reflected in local terminologies such as ekum asase (land degradation), esei kwae (deforestation), sika bonsam (money that it generation drives people insane) and ehyekro (destroy community). Two major points are noteworthy from these definitions: first they were common in all the three major mining settlements and their catchment areas that we studied; second and most importantly they underlie three key areas that were recurrent during our interviews - environment, social and economic issues. Before we draw upon empirical data from our interviews to discuss these three domains and how they are driven by industrial waste from mining activities in the study area, we give a summary of a 56 year-old female respondent understanding of the negative impact of mining:

We have been made to believe since my infancy that citrus from our community is sweet and have even been given a label as "Obuasi ankaa wo" (to wit, the sweet as honey citrus of Obuasi). But little did we know that citrus and other agricultural products as well as our drinking water are deadly contaminated with poisonous substances that we cannot see with our naked eyes. Several diseases and sudden deaths which were attributed to witchcraft in the past, we now know have their bearings in the discharge of industrial waste from the mines in our community (Adwoa Agyeikumwaa, Obuasi, per comm.,2010)

The above demonstrates the depth of local peoples' understanding of the threat industrial waste from mining activities poses to lives and livelihoods. However, we found from our study that most respondents considered the mining companies so powerful that they have resigned themselves to the situation (Babut, et al., 2003; Hilson \& Yakovleva, 2007; Bush, 2009). For example, we found across our study settlements when we asked our respondents of community members filing claims for compensation for deaths related to poisonous industrial waste from mining such as cyanide and mercury, most respondents said these were unheard of. But most of our respondents associated strange illnesses and some deaths in the communities with environmental pollution from mining activities, particularly the seepage of poisonous chemicals into water bodies (see for example Hayford et al., 2008:2). In the Tarkwa area and its environs for instance, many people had reportedly left villages where water quality has deteriorated to the extent that they no longer feel safe (Akbazaa \& Darimani, 2001:46).

In addition to water pollution, negative environmental impact of industrial waste from mining was traced to loss of livelihoods. In our focus group discussions, many people, especially 
young men and women were critical of declining soil fertility in their communities which have negatively impacted on farming, the main occupation. They attributed this to massive land degradation by artisanal miners who they claimed used various chemicals which rendered the "soil dead". For instance, at Ahafo Kenyasi area, one of our respondents had this to say:

These people (artisanal miners) are everywhere and are "killing the land". Their activities are so destructive to the land that after they have left a piece of land it may take several generations before the land recovers. They do not care about our farms. In so far as they find gold on the land they will go for it. We are helpless because it appears some of our traditional leaders are in league with them. In addition, they are often armed and we cannot approach them, especially in those remote areas where we have our farms (Kwaku Agyapong, Ahafo Kenyasi, per comm.., 2010).

Indeed agriculture, the main source of livelihood in mining communities, has been seriously affected due to land degradation (Akabzaa and Darimani, 2001; Hayford, et al., 2008). For example, Akabzaa \& Darimani (2001: 47) found that in most parts of Tarkwa, the environment is undergoing rapid degradation and its immense economic value is diminishing from year to year, due mainly to the heavy concentration of mining activities in the area. They also noted that agricultural lands are not only generally degraded, but the decrease in land for agricultural production has also led to a shortening of the fallow period from 10-15 years to 2-3 years. Thus in the Tarkwa area and our other two study communities, we found that land degradation has translated into many social and economic problems. For example, we found that many families were unable to adequately cater for their basic nutritional requirements either due to loss of their farm lands through government concessions to mining companies or indirectly through land degradation due to pollution from industrial waste of mining entities. This finding on industrial waste and land degradation has also been observed by Hilson (2002b: 54) with respect to small-scale mining as below:

....mercury, which is used in excessive quantities in mineral refining processes, has been released uncontrollably into natural ecosystems surrounding operations, accumulating to toxic levels in soils, water bodies and flora. Perhaps more important, however, is that small-scale gold mining, as a migratory activity, has caused a significant amount of land damage in Ghana.

We found that in addition to land degradation which directly affects agriculture the main stay of the local economies in our study area, there has been recognisable impact in terms of income disparities which has been introduced into the communities by mining. For instance, many of our women respondents attributed the cost of living in their communities, which they claimed had increased more than fivefold, mainly to mining. They attributed this to money that artisanal miners have and are able to buy whatever at any price and also because of declining food production due to land degradation. High cost of living as a result of income disparities have been observed in several mining communities in Ghana including our study communities (see for example Akabzaa \& Darimani, 2001:48). In the Ahafo Kenyasi area for example, we found from focus group discussions that many families have relocated outside the community. Some of the respondents said these people though benefitted from housing resettlement schemes have had to leave the communities because they no longer had adequate land to farm and the cost of living in the community had also become too high (Bureau of Integrated Rural Development, 2009a).

Results from our interviews in the communities also established that there was not much community-mining companies' engagement to address some of the issues raised above 
particularly regarding industrial waste management. Although we found that waste recycling technologies were being used by some mining companies to deal with the large volumes of industrial wastes they generate, there is still a long way to go in this direction. And with the ubiquitous artisanal miners we found no such inclination to deal with their waste.

Indeed as demonstrated above, the negative socio-economic consequences of mining waste in the study area and across Ghana can be tremendous. For example, literature exist on the metal pollution within the environment of mining communities in Ghana (Adimado and Amegbey 2003; Akabzaa et al. 2005; Carbo and Serfor - Armah 1997; Essumang et al 2007; Hilson 2002a; Manu et al 2004; Obiri 2007; Yidana et al 2008) but not much has been done on tackling the problem from the indigenous local people`s perspective, which is one of the key concerns of this chapter.

Literature on the mining industry in Ghana show that the corresponding damage to the environment and its effects on the people living in the mining communities far outweigh the benefits deriving from it. As at 1998, the government of Ghana had granted over 200 mining leases to companies. This means that about 30\% of Ghana`s land surface is being mined, implying that the volume of mining related hazards particularly, wastes and its attendant environmental degradation is growing at an alarming rate. Interestingly, these mining activities are mostly found in the environmentally and socially vulnerable areas.

The Environmental Impact Assessment (EIA) is usually carried out as required by law in Ghana by the Environmental Protection Agency (EPA) before the mining companies are allowed to operate. Initially, these companies would present a very convincing arrangement to operate with the barest minimum negative impact on life and property. But as soon as they are granted permission to operate, they renege on their own control measures. This is exemplified by a number of cyanide spillages, damping mining waste into water bodies, destruction of farm lands and so on. For instance, a study has shown that Arsenic, Cadmium, and Mercury are found in food crops such as cocoyam (Xanthosoma sagititolium) and Watercocoyam (Colocasia esculenta) in Tarkwa, a prominent Mining Community in Ghana (Essumang et al., 2007). There has been widespread tension between mining companies and the local people over the destruction of farmlands and the general disregard for the rights of the local people by the mining companies. More often than not, the military, police and other paramilitary groups are used by these mining companies to brutalise the protesters into submission. Deaths and serious injuries are usually reported by the local media on such inhuman behaviour of the mining companies.

There have been incessant complaints from the local people that these mining companies which are multinational in nature do not employ local people. For instance, our interaction with the people of the study areas revealed that the mining companies prefer labour from outside the mining areas. Meanwhile it is the local people who bear the brunt of their (mining companies) activities. For example, mining activities, particularly surface mining, have resulted in the alienation of large tracts of land from communities, depriving poor and marginalised communities of their land surface rights, and as a result depriving many communities of their sources of livelihood (Akabzaa, 2009). The appropriation of the land of local communities for mining has often engendered social upheavals and adversely impacted on the routine livelihood activities of these communities. Such social upheavals are commonplace in communities affected by mining projects in Ghana (Akabzaa, 2009). 
Furthermore, we realised from our interactions with the local people that the mining companies are not paying adequate compensation to affected farmers based on the compensation principles in the Minerals and Mining Law (Act 703). The people from the study areas also emphasised that it is not only multinational companies whose actions are destroying the environment but also the activities of illegal miners whose method of mining has been tagged in Ghana as galamsey. This is a form of artisanal mining for gold and diamond. These illegal miners also carry out alluvial mining in some rivers. These miners troupe from all areas of Ghana into the mining areas to carry out their illegal activities. What is worrisome about this category of miners is that they lack the requisite technology and safety measures needed in mining. The open mining pits they leave behind have become death traps to people and livestock. They wash the ore directly in rivers and thus pollute these rivers with all sorts of chemicals particularly mercury. Because of the bad mining methods, mining related diseases such as tuberculosis, diarrhoea, buruli ulcer, pneumoconiosis, lung cancer and other occupational respiratory diseases are a common feature in the mining communities in Ghana. Generally, we found out that even though there exists the Mercury Law (PNDCL 217), SmallScale Gold Mining Law (PNDCL 218), and Precious Minerals and Marketing Law (PNDCL 219) in 1989, the level of their enforcement leaves much to be desired.

\section{Types of mining waste in Ghana and their impacts}

Mining extraction in Ghana centre mainly on activities such as: Removal of overburdens and ore blasting; loading and hauling of ore to the processing plant; beneficiation (the processing of ore); disposal of waste generated from the ore processing; drainage of mine area and discharge of mine waters. Therefore, the mineral waste generated in Ghana result from the above activities. Specifically, the following are the main mining wastes in Ghana: waste rocks, open mine pits, disposal of mining waste usually these are damped into water bodies, atmospheric pollution (tailing from the mill and ore processing plants), chemical pollution of the land, and frequent cyanide spillage.

According to Hayford et al. (2008), the processing of the ore body and its waste product disposal method are the major source of environmental pollution. They indicate further that as typical of most mining operations in the country as elsewhere, the tailings that consist of crushed ore and rock bodies after most of the needed metals have been removed are often toxic and pose serious threats to human, animal and plant life (Hayford et al., 2008:2). Mercury has particularly been noted as a major pollutant, especially from the activities of small-scale miners (Amankwah \& Sackey, 2002; Hayford et al., 2008). Cyanide spillage has also become a major source of concern (Anane, 2001).

The sedimentation ponds containing trailing where future treatment is done has been noted to be major source of supply of the industrial waste from mining (Hayford et al., 2008:2). The sedimentation ponds contain sulphides (pyrites, arsenopyrites, etc.), which are oxidized in the tailings. The resultant acidic effluent water in the sedimentation ponds leach out elements such as mercury, arsenic, zinc, copper, vanadium, antimony and chromium (Hayford et al., 2008). The effluent subsequently ends up in nearby streams and rivers, introducing its dissolved toxic elements into them.

The environmental degradation from mining activities and its related industrial waste is evident in several forms. In Ghana those that are of great concern include atmospheric 
pollution, water pollution, land degradation and deforestation (Amankwah \& Sackey, 2003:134). In our study communities as elsewhere in Ghana, the activities of small scale miners were noted by our respondents to be of major concern (see discussions on Negative Impact of Mining above). In Ghana, the environmental destruction caused by the unplanned and sometimes dangerous and irrational methods used by small-scale miners has been noted (Amankwah and Sackey, 2003).

Water pollution remains the major challenge in several mining communities countrywide. And as already noted in our study communities, this emanates from effluent from sedimentation ponds which subsequently ends up in nearby streams and rivers, introducing its dissolved toxic elements into them (Hayford, et al, 2008). This has resulted in increases in health problems, like severe intestinal upsets, keratosis and skin cancer (Steinnes \& Berg, 1998; Akabzaa \& Darimani, 2001; Hayford et al., 2008). There have also been several instances of cyanide spillage in water bodies which has resulted in fatalities (Anane, 2001). Regarding atmospheric pollution, our respondents were quick to mention air pollution generated from dust from bulldozing and transport activities. Several of our respondents talked about coughs and chest problems which they attributed to dust particles.

Noise pollution from blast was also mentioned. In the latter, many of our respondents referred to cracks in the local buildings as partly to do with this operational activity of the mining companies. Literature points to the fact that mining communities in Ghana are victims of air, noise and water pollution as well as other forms of environmental degradation from mining companies (see for example, Akabzaa \& Darimani, 2001:34). For example, Akabzaa and Darimani (2001) make reference to the release of airborne particulate matter into the environment, particularly minute dust particles of less than 10 microns which they emphasize as a serious health threat to the people of the Tarkwa, one of our study communities. All fine dust at a high level of exposure has the potential to cause respiratory diseases and disorders and can worsen the condition of people with asthma and arthritis. Dust arising from gold mining operations has a high silica content which has been responsible for silicosis and silico-tuberculosis in the area (Akabzaa and Darimani, 2001:55). The situation regarding industrial pollution and perhaps the apparent helpless situation of the mining communities emanates from what has been noted about mining projects that they generally have weak links with the rest of the host national economy, although they can have a decisive impact on the communities in which or near which the mines are located (Kwesi Anyemedu, 1992, cited by Akabzaa \& Darimani 2001:35).

\section{The role of indigenous people in mitigating the problem of mining waste in Ghana}

Our previous studies (Sarfo-Mensah, 2002; Awuah-Nyamekye, 2009; Sarfo-Mensah and Oduro 2010) have shown that traditional Ghanaians` lifestyle is environmentally friendly. This is as the result of their worldview ${ }^{2}$, which is hugely underpinned by their religion.

\footnotetext{
2 By worldview of the local people, we mean what Mkhize (2004: 2-4) refer to as the set of basic assumptions of the people developed in order to explain reality and their place and purpose in this world. In other words, and to borrow Elkins' (1938:133, quoted in Rose, et al. 2003:59) words, worldview is " a view of nature and life, of the universe and man, which unites them with nature's activities and species' in bond 'of mutual life-giving."
} 
Indigenous Ghanaians ascribe spiritual qualities to everything that constitutes nature. Thus, for them, forests, rivers and other natural endowments connote more than the eye can see. Behind these natural phenomena, is a socio-cultural dimension, particularly their spiritual connectedness to these resources that have as much value as their physical manifestations. Indeed, traditional Ghanaians interpretation of nature (environment) is not different from culture (society) and they feel that these two mutually influence each other and the two underpin their heritage and very existence (Sarfo-Mensah and Oduro, 2010). This explains why indigenous Ghanaians will not pollute a river with dangerous chemicals. For instance, bathing or washing in a river is strictly prohibited. This is to prevent the chemical content of the soap from polluting the river and thereby endangering marine life (pers. comm. 3 July 2011). It is against this backdrop that African indigenous religion has been referred to as 'profoundly ecological' (Schoffeleers, 1978).

And within the mining sector, especially among artisanal miners, there is a lot of belief around precious minerals and local gods. This consequently impact on the conduct of their practices including how they treat rivers, sacred groves and other areas designated as the domain of local gods, such water heads, hills and mountainous areas which are potential areas for mining . For example, Addei and Amankwah (2011:249) relate that some major activities of artisanal and small scale gold miners in Ghana are to a large extent informed by superstitious beliefs and myths. They emphasize that each major activity such as prospecting/mining and processing of the precious metal are controlled by specific beliefs, and since mining activities take place around large rivers, sacred groves and forests, the belief that these bodies have inherent supernatural powers, demands that specific set of rules be observed (Addei and Amankwah, 2011:249). Indeed, the belief is not only limited to the artisanal mining but also relates to the formal big mining sector as Addei and Amankwah (2011:249) underscore below:

Oral traditions indicate that early miners in underground mines in the now AngloGold Ashanti Mine in Obuasi and the defunct Prestea Mine met small creatures purported to be dwarfs in underground tunnels and in some cases hens and chickens. These spirit beings saw the miners as intruding into their private spaces and miners had to pacify them in order to work safely.

Another classic and interesting example found by Addei and Amankwah (2011) relates directly to beliefs concerning industrial waste. They claim that the first heap of waste built by the defunct Teberebie Goldfields could not be leached due to problems of lixiviate percolation. They contend that though the metallurgists thought that it had to do with the binder used, some opinion leaders in the community were of the view that it was because sacrifices had not yet been made to the gods of the land. To satisfy both schools of thought, a cow was sacrificed while the binder was changed to Portland cement. They further point out that on other mines, new earth moving equipment have been rendered irreparable after local people said unidentified white men were seen using them on a night shift (Addei and Amankwah, 2011: 249).

This implies that indigenous people`s beliefs and ecological knowledge, which is underpinned by their religion can be roped in when addressing environmental problems caused by mining activities, especially in the area of managing waste. But unfortunately, indigenous ecological knowledge and beliefs are often neglected by policy-decisions makers in Ghana. 
It is regrettable, however, to note that traditional strategies and institutions to address environmental problems are under threat. A recent studies and elsewhere in Africa (SarfoMensah and Oduro, 2010; Nwosu, 2010) in some Akan communities in the transitional agroecological zone of Ghana to investigate the spirituality of forests and conservation reveals that tumi (the traditional belief in super natural power suffused in nature by Onyame, the Supreme Creator Deity) and suro (the awesome reverence and fear) that were usually attached to nature are waning (see also Ntiamoa- Baidu 1995; Abayie Boateng 1998; AppiahOpoku and Hyma 1999). This is partly attributed to the changes in the perceptions and attitudes of local people towards their worldview. For instance, our study revealed that certain forests which had been designated as sacred and thus their entry is limited to a few people have been cleared for mining.

Similarly, the 26th September edition of the national paper, Daily Graphic reports of the damping of waste from a wood treatment company in Takoradi into the Butuah lagoon which has resulted in the death of more than 40000 fishes in the lagoon. The report adds that those who ate the dead fishes suffered stomach running and dehydration and had to be sent to hospital (Daily Graphic 26 September 2011). This could not have happened when the day-to-day administration of the country was under the authority of the local chiefs who doubled as political and religious leaders.

Christianity is largely blamed to be responsible for this change in local perceptions and attitudes due to its sustained attack on African indigenous religion. Different studies on traditional people across Africa confirm this view (Parrinder 1961; Smith 1986:86; Nukunya 1986: 87; Juhe- Beaulaton 2008; Nwosu, 2010; Western Regional Directorate of CNC 2010; Teye 2010; Opoku-Ankomah et al. 2010). This seems to collaborates Lynn White`s 1967 view that Christianity is to blame for the world's current environmental crisis although Lynn's view has been challenged (Joranson and Butigan 1984; Harrison 1999; Johnson 2000).

But it should be explained that Christianity is being blamed not because it is seen as anti environmental conservation per se, but the blame is in respect of its persistent attack on the indigenous religions which underpins the traditional conservation methods. Ghanaians and, for that matter, Africans are generally seen as 'incurably' religious (Parrinder 1974: 9). Consequently, their social and moral laws are believed to be divinely inspired and thus enforced through the agency of religion, so anything that affects their religion affects their laws. The only instance in Africa where a study's result seems to challenge the hypothesis that Christianity is to blame for loss of nature resources, particularly the forest, is that among the Muzarabani of Zimbabwe (Byers et al. 2001). The researchers, however, stated that about three-quarters of the people interviewed claimed to hold allegiance to both the local religion and Christianity. This indeed makes this challenge suspicious.

We also found among our respondents that most of them, as proven by other studies in Ghana (see for example, Awoonor, 1975; Adarkwa-Dadzie, 1998; Sarfo-Mensah, 2007; Opoku Ankomah, et al. 2010; Addei and Amankwah, 2011) were syncretic and that they were prone to be easily swayed by Christianity and Islam in their public conduct but were inherently superstitious and inclined to believe in traditional religion. But what we found worrisome, though, was the extent of deprivation in the study communities. It made many local people easy prey to economic motivations to become local collaborators for denigrating sacred areas and other natural resources including rivers and water bodies, actions which hitherto were considered taboo. Indeed, some local institutions were also 
found to be vulnerable to economic pressures. They sometimes either directly collaborated with mining concerns which were found to degrade the environment or turned blind eye because of inducements from miners, especially itinerant small-scale miners. For instance, Chieftaincy which is considered the bastion of culture and custodian of land and its related natural resources in the study area, was blamed by some respondents for the activities of recalcitrant artisanal miners.

\section{The way forward}

Based on the above findings, the following recommendations are made. There is the need for urgent amendment to the Mineral and Mining Laws in Ghana to be more binding on mining companies to comply with mining regulations. It is imperative that measures are put in place for a routine check on mining companies to make sure they comply with the environmental safety standards set especially in the area of illegal disposal of industrial wastes. This can effectively be done if there is a greater co-ordination in the implementation of waste management plans and programmes by the relevant agencies.

We also suggest that it is time for a comprehensive engagement of all stakeholders in the mining industry to evolve a strategy that will enhance mutual and harmonious co-existence between the formal mining sector (i.e. recognized big companies) and the small-scale sector which encourages the latter to adopt sound mining practices. This strategy should, among others, be geared towards achieving a regulatory tenure framework which will deal comprehensively with the incessant encroachment of land by artisanal miners. The overwhelming majority of small scale miners operate without security of tenure and any legal entitlement (Hilson and Potter, 2005).

There should be a constant sensitisation of the local people on their right to adequate compensation from mining companies and to keep 'eagle eye' on the mining companies particularly the way wastes from their operations are disposed off. This will enable them to report the bad activities of the mining companies to the appropriate quarters for disciplinary action.

It is also recommended that a framework is adopted which will enable or encourage more private companies to invest in waste management sector of the economy.

We further recommend that the Environmental Protection Agency (EPA) is adequately resourced to be able to do its work well and efficiently especially in its assessment and monitoring oversight role. This will also enable it to liaise well with the District Environmental Management Committees (DEMC). Additionally, EPA must put measures in place to enable it to constantly monitor and evaluate the activities of the mining companies especially with regard to their impact on the environment of the areas they operate. This can assist the EPA to revise its laws to meet the realities on the ground. Also in this direction, we suggest that EPA increases its activities to promote environmental improvement in smallscale gold mining operations which arguably have been noted to have caused disproportionately large share of environmental degradation (Hilson, 2002b).

It is furthermore recommended that policy-decisions makers set up special fund for the relevant agencies like the universities and other analogous institutions to conduct further research with the view to finding the most appropriate ways of dealing efficiently with the problem of industrial waste, particularly in the mining section in Ghana. 
We also recommend that government begins a serious consideration for a comprehensive support package for the small-scale mining sector due to its huge employment creation capacity and its financial contribution to the economy. The support package, we suggest, should focus more on capacity development both in terms of environmental and ethical training as well as financial to enable them purchase relevant equipment that would make their operations environmentally sustainable.

\section{Conclusion}

The foregoing discussions have not only examined the concept of industrial wastes with particular reference to mining but have also focused on the complex long historical development background of the mining industry in Ghana. Related issues such as the effects of mining hazardous or toxic materials especially the wastes which pose real and potential danger to the lives of the people and the environment as a whole in Ghana, the local people`s environmental conservation strategies, as well as the role of indigenous people in mitigating the problem of mining waste in Ghana have been examined. The discussions have also pointed out the fact that over the years, the mining industry has contributed its quota to the development of the economy of Ghana. This notwithstanding, the poor manner in which the waste resulting from the industry especially the hazardous ones are managed is creating doubts in the minds of people especially environmentalists and eco-friendly minded-people about the actual benefits of the industry to local people and the country as a whole.

It is imperative to stress that the study also is not by the picture thus far painted, suggesting the banning of mining in Ghana, but rather, advocating the application of sustainable mining techniques to reduce risks posed by mining wastes to human life, the environment and also enable Ghanaians to enjoy the socio-economic benefits of the industry and at the same time conserving the natural resources -- our heritage. To be able to do this effectively, there is the urgent need to re-examine the mining industry by taking the above recommendations into consideration.

\section{References}

Abayie Boaten, A. 1998. Traditional conservation practices: Ghana's example. Institute of African Studies Research Review, Vol. 14, No 1, pp. 42-51.

Adadey, E. (1997).The role of the mining industry in the economy of Ghana: The mining industry and the Environment, Proceedings of a National Symposium, UST/IDRC Environmental Research Group: Kumasi, Ghana, April, 14 \&15.

Adarkwa-Dadzie, A. 1998. 'The Contribution of Ghanaian Traditional Beliefs to Biodiversity Conservation', in Amlalo D.S., L. D. Atsiatorme and C. Fiati (eds.), Proceedings Of The Third UNESCO MAB Regional Seminar On Biodiversity Conservation And Sustainable Development In Anglophone Africa (BRAAF), Cape Coast, 9-12th March 1997. Accra: Environmental Protection Agency (EPA).

Addei, C. and Amankwah, R. K. (2011). Myths and Superstition in the Small Scale Gold Mining Industry of Ghana Research Journal of Environmental and Earth Sciences, Vol. 3 No. 3 pp. 249-253. 
Adimado A., A.; Amegbey N., A. (2003). Incidents of cyanide spillage in Ghana, Mineral Processing and Extractive Metallurgy. (Trans. IMMC) 112, 2.

Agra, V. (1997). Current environmental practice in the mining industry: The mining industry and the Environment, Proceedings of a National Symposium, UST/IDRC Environmental Research Group: Kumasi, Ghana, April, 14 \&15.

Akabzaa, T. M., Banoeng - Yakubo, B. K. And Seyire, J. S. (2005): Impact of Mining Activities on Water in the Vicinity of the Obuasi Mine.

Akabzaa, T. M. and Darimani, A. (2001). Impact of Mining Sector Investment In Ghana: A Study Of The Tarkwa Mining Region. A Draft Report Prepared For SAPRI.

Amankwah, R.K. and Anim-Sackey, C. (2003). Strategies for sustainable development of the small-scale gold and diamond mining industry of Ghana. Resources Policy, 29 (2003): 131-138.

Amevor, S. (2006) Ghana: Mining is killing Agricultural sector says Wacam (Public Agenda, 6 June, 2008).

Anane, M. (2001). Another Cyanide Spillage in Ghana. MAC: Mines and Communities, In: FIAN International. Accessed on 28 September, 2011. Available from: <http://www.minesandcommunities.org/article.php?a=1077>.

Appiah-Opoku, S. and B. Hyma. 1999. Indigenous institutions and resource management in Ghana'. Indigenous Knowledge and Development Monitor, vol. 7 no. 3 pp. 15-17.

Awoonor, Kofi. (1975). The breast of the Earth: A survey of the history, culture, and literature of Africa south of the Sahara. Anchor Press: Garden City, N.Y., 387 p.

Awuah-Nyamekye, S. (2009a). Teaching sustainable development from the perspective of indigenous spiritualities of Ghana, In: religion and sustainable development opportunities and challenges for higher education, Cathrien de Pater \& Irene Dankelman (eds.), pp. 22- 39, Lit Verlag Fresnostr, ISSBN 978-3-643-90017-3, Berlin.

Awuah-Nyamekye, S. (2009b). Salvaging nature: the Akan religio-cultural perspective, World Views: Global Religions, Culture, and Ecology, Vol. 13, No. 3. pp. 251- 282, ISSN 1363-5247.

BIRD. (2009) a. Newmont Ghana Gold Limited Ahafo Mine, External Stakeholder Perception Study, Final Report prepared by Bureau of Integrated Rural Development (BIRD), Kwame Nkrumah University of Science and Technology, Kumasi, Ghana.

BIRD, (2009) b. Newmont Ahafo Development Foundation Mine, Training of Sustainable Development Committees from ten communities in the Newmont Ahafo Mine Area, Final Report prepared by Bureau of Integrated Rural Development (BIRD), Kwame Nkrumah University of Science and Technology, Kumasi, Ghana.

Babut, M. R. et al. (2003). Improving the environmental management of small-scale gold mining in Ghana: a case study of Dumasi, Journal of Cleaner Production, 11 (2003), pp. 215-221.

Bush, R. (2009).Soon there will be no-one left to take the corpses to the morgue': Accumulation and abjection in Ghana's mining communities, Resources Policy, Vol. 34, no. 1-2, March-June 2009, pp. 57-63.

Brooks, R.R, et al. (1976). Mercury and other heavy metals in trout of central North Island, New Zealand. New Zealand Journal of Marine and Freshwater Research, 10, 233244.

Byers, B. A. et al. (2001). Linking the conservation of culture and nature: A case study of sacred forests in Zimbabwe' in Human Ecology, Vol. 29, No. 2, pp. 187-218. 
Carboo, D., Serfor-Armah, Y. (1997). Arsenic in stream and sediments in Obuasi area. Proceeding of the symposium on the mining industry and the environment KNUST/IDRC 1997, 114 - 119.

Coakley, G. J. (2003). The Mineral Industry of Ghana. United Sates Geological Survey Minerals Yearbook-2003. Washington DC. Accessed 27 September, 2011 Available from:

< http://minerals.usgs.gov/minerals/pubs/country/2003/ghmyb03.pdf>.

Chaudhary R., Rachana M., (2006). Factors affecting hazardous waste solidification/stabilization: A Review. In: Journal of Hazardous Materials B137 pp. 267-276.

Essumang, D., K. Et al. (2007). Arsenic, Cadmium, and Mercury in Cocoyam (Xanthosoma sagititolium) and Watercocoyam (Colocasia esculenta) in Tarkwa, a Mining Community. Bulletin of Environmental Contamination and Toxicology 79:377-379.

Ghana Statistical Services. (2010). Ghana Population and Housing Census. Government of Ghana, Accra.

Harrison, Peter.1999. Subduing the earth: Genesis1, early modern science, and the exploitation of nature, in The Journal of Religion, Vol. 79, no.1, pp 86-- .

Hayford E. K. et al . (2008). Impact of Gold Mining on Soil and some Staple Foods Collected from Selected Mining Communities in and around Tarkwa-Prestea Area, West African Journal of Applied Ecology, (14): 1-12.

Hilson, G. (2001). A Contextual Review of the Ghanaian Small-scale Mining Industry. Report commissioned by the (MMSD) project of IIED.

(2002a). An overview of land use conflicts in mining communities. Land Use Policy 19(1): 65-73.

-(2002b). Promoting sustainable development in Ghanaian small-scale gold mining operations. The Environmentalist, 22, 55-57.

Hilson, G. and Potter, C. (2005). Structural Adjustment and Subsistence Industry: Artisanal Gold Mining in Ghana Development and Change 36(1): 103-131 (2005).

Hinton J. J. , Veiga, M. M. and Beinhoff, C. (2003). Women and Artisanal Mining: Gender Roles and the Road Ahead, In ed. Hilson, G. The Socio-Economic Impacts of Artisanal and Small-Scale Mining in Developing Countries. A. A. Balkema, Swets Publishers, Netherlands, Chapter 11, pp. 52

Jehu-Beaulaton, D. (2008). Sacred Forests and the Global Challenge of Biodiversity Conservation: The Case of Benin and Togo, In: Journal for the study of Religion, Nature and Culture, Vol. 2 no.3, pp. 351-372, ISSN 1363-7320.

Johnson, Philip N. and Butigan, Ken (eds.). 1984. Cry of the environment: Rebuilding the Christian creation tradition. Santa Fe, NM: Bear and Company.

Johnson, William T. (2000). The Bible on Environment Conservation: A 21st Century Perspective, In: Quodlibet Journal, Vol. 2 No. 4. Accessed 29 December 2010. Available from:

<http:www.quodlibet.net/articles/Johnson-environment.shtml>.

Kesse, G. O. (1985). The Mineral and Rock Resources of Ghana. Journal of African Earth Sciences (7): 601-610.

Leonard, J. and Robinson, G., Eds. (2009). Managing Hazardous Materials. Institute of Hazardous Materials Management. 
Manu, A. et al. (2004). Application of Remote Sensing and GIS Technologies to Assess the Impact of Surface Mining at Tarkwa, Ghana. Geoscience and Remote Sensing Symposium IGARSS '04 Proceedings. IEEE International 1:572- 574.

MGM ( 2010). Regional profiles of Ghana. Modern Ghana Media. Accessed 28 September, 2011. Available from:

<http://www.modernghana.com/GhanaHome/regions/ashanti.asp?menu_id=6\& men u_id2=14\&sub_menu_id=131\&gender $=>$.

Minerals Commission (2004). Ghana Minerals Commission, 2004. Annual Report for 2003 (Self Published).

Mkhize, N. (2004). Psychology: An African perspective. In ed. Ratele, K., N. Duncan, D. Hook, N. Mkhize, P. Kiguwa and A. Collins. Self, Community and Psychology. Lansdwone: UCT Press, Republic of South Africa., Chapter 4.

Moreno, F.N, et al. 2009. Analysis of mercury-rich plants and mine tailing using the hydridegeneration AAS method.

Munson-McGee S.H., Parsa, J., Steiner, R., 1996. Stabilization/solidification of hazardous wastes using fly ash. In: Journal of Environmental Engineering, 122 (10), pp. 935940.

Ntiamoa-Baidu, Yaa. (1995). Indigenous versus introduced biodiversity conservation strategies; The case of protected areas in Ghana. Biodiversity support program (Issue in African Biodiversity No. 1) Washington, DC.

Nwosu, P.U. 2010. 'The Role of Okonko Society in Preserving Igbo Environment' in Journal of Human Ecology, Vol. 31, no. 1, (2010), pp. 59-64.

Obiri, S. (2007). Determination of heavy metals in boreholes in Dumasi in the Wassa West District of Western Region of the Republic of Ghana. Environmental monitoring and assessment 130: 455-463.

Opoku-Ankomah, Y, et al. 2010. 'Research Findings in Water bodies: The human and Cultural factors and their impact on the Environment', in Report of the National Conference on Culture and Water organised by the National Commission on Culture at Akosombo, 24- 26 ${ }^{\text {th }}$ February 2010.

Orloff, Kenneth, and Henry Falk. 2003. An international perspective on hazardous waste practices. International Journal of Hygiene and Environmental Health 206 (4-5):291302.

Owusu-Koranteng, H. 2008. Report WACAM-DKA collaboration: Preliminary review of the Alternative Livelihood Project (ALP) of Goldfields Ghana Limited.

Parrinder, E. Geoffrey. 1961. West African Religions: A Study of the Beliefs and Practices of Akan, Ewe, Yoruba, Ibo and Kindred peoples. London: The Epworth Press.

Parrinder, Geoffrey. 1(974). African Traditional Religion $3^{\text {rd }}$ ed. London: Sheldon Press.

Regional Directorate of Centre for National Culture, Western Region. 2010. Culture as a vehicle for Wealth creation and Socio-economic Development', in Report of the National Conference on Culture and Water organised by the National Commission on Culture at Akosombo, 24- 26 th February 2010.

Rose, D., James, D and Watson, C. (2003). Indigenous kinship with the Natural World in New South Wale. New South Wales National Park and Wildlife Services.

Sarfo-Mensah, P and Oduro, W. 2007. Traditional Natural Resources Management Practices and Biodiversity Conservation in Ghana: A Review of Local Concepts and Issues on Change and Sustainability. NOTA DI LAVORO 90.2007 Available on line at: 
http://www.feem.it/Feem/Pub/Publications/WPapers/default.htm.

Last accessed 20 Aug, 2011.

Sarfo-Mensah, P. et al. (2010)a Traditional Representations of the natural environment and biodiversity conservation: Sacred groves in Ghana.. In: Fondazione Eni Enrico Mattei Working Papers, Accessed 20 November 2010, Available from:

< http://www.bepress.com/feem/papers398>.

Sarfo-Mensah, P. et al. (2010)b. Youth Unemployment Challenges in Mining Areas of Ghana. NOTA DI LAVORO, 122.2009, GLOBAL CHALLENGES Series Fondazione Eni Enrico Mattei, web site: www.feem.it, e- mail: working.papers@feem.it.

Schoffeleers, J. M. (ed.). 1978. Guardians of the Land: Essays on Central African Territorial Cults. Harare, Zimbabwe: Mambo Press.

Steinnes E. and Berg T. (1998). Significance of Long-Range Atmospheric Transport for Heavy Metal and Radionuclide Contamination of Terrestrial Environment. Am. Mineral. 80: 429-443.

Teye, Joseph K. 2010. 'Network Management of Water Resources in Ghana : A Framework for Integrating Traditional and Scientific Methods', in Report of the National Conference on Culture and Water organised by the National Commission on Culture at Akosombo, 24- 26 th February 2010.

The Ghana Chamber of Mines (2005). "The impact of mining on local economy". Annual report of the Chamber mines. Accra, Ghana.

The UNC. (2010). 18th Session of the United Nations Commission on Sustainable Development, National Report for Ghana Waste Management in Ghana).

Tsikata F. S. (1997). The vicissitude of mineral policy in Ghana. Resource. Pol. Vol. 23, no.1/2, pp.9- 14.

White, Lynn. 1967. The historical roots of our ecological crisis. Science 155 (3767): 1205-1207.

Yidana, S.M. et al (2007). A multivariate statistical analysis of surface water chemistry data in The Ankobra Basin, Ghana. Journal of Environmental Management 86: 80-87. 


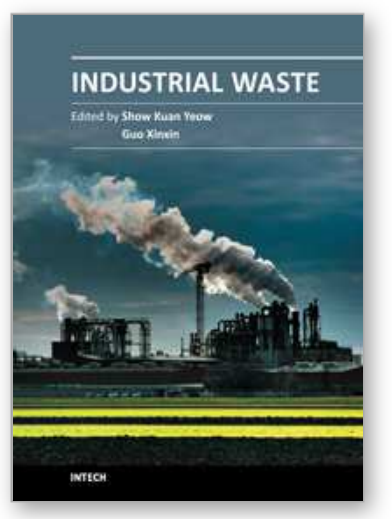

\author{
Industrial Waste \\ Edited by Prof. Kuan-Yeow Show
}

ISBN 978-953-51-0253-3

Hard cover, 274 pages

Publisher InTech

Published online 07, March, 2012

Published in print edition March, 2012

This book is intended to fulfil the need for state-of-the-art development on the industrial wastes from different types of industries. Most of the chapters are based upon the ongoing research, how the different types of wastes are most efficiently treated and minimized, technologies of wastes control and abatement, and how they are released to the environment and their associated impact. A few chapters provide updated review summarizing the status and prospects of industrial waste problems from different perspectives. The book is comprehensive and not limited to a partial discussion of industrial waste, so the readers are acquainted with the latest information and development in the area, where different aspects are considered. The user can find both introductory material and more specific material based on interests and problems. For additional questions or comments, the users are encouraged to contact the authors.

\title{
How to reference
}

In order to correctly reference this scholarly work, feel free to copy and paste the following:

Samuel Awuah-Nyamekye and Paul Sarfo-Mensah (2012). Mining or Our Heritage? Indigenous Local People's Views on Industrial Waste of Mines in Ghana, Industrial Waste, Prof. Kuan-Yeow Show (Ed.), ISBN: 978-95351-0253-3, InTech, Available from: http://www.intechopen.com/books/industrial-waste/mining-or-our-heritageindigenous-local-people-s-views-on-industrial-waste-of-mines-in-ghana

\section{INTECH}

open science | open minds

\author{
InTech Europe \\ University Campus STeP Ri \\ Slavka Krautzeka 83/A \\ 51000 Rijeka, Croatia \\ Phone: +385 (51) 770447 \\ Fax: +385 (51) 686166 \\ www.intechopen.com
}

\author{
InTech China \\ Unit 405, Office Block, Hotel Equatorial Shanghai \\ No.65, Yan An Road (West), Shanghai, 200040, China \\ 中国上海市延安西路65号上海国际贵都大饭店办公楼405单元 \\ Phone: +86-21-62489820 \\ Fax: $+86-21-62489821$
}


(C) 2012 The Author(s). Licensee IntechOpen. This is an open access article distributed under the terms of the Creative Commons Attribution 3.0 License, which permits unrestricted use, distribution, and reproduction in any medium, provided the original work is properly cited. 